\title{
Synthesis and Characterization of a Linker for Primary Amines used in the Solid Phase Organic Synthesis of Spermidine
}

\author{
Emerson T. da Silva, ${ }^{a}$ Rosane A. S. San Gil, ${ }^{*, a}$ Stefano Caldarelli, ${ }^{b}$ Fabio Ziarellic and \\ Edson L. S. Lima ${ }^{a}$
}

anstituto de Química, Universidade Federal do Rio de Janeiro, CP 068556 (Ed.CT), 21945-970 Rio de Janeiro-RJ, Brazil

${ }^{b}$ Aix-Marseille Université ISm2 UMR 6263 Campus de Saint Jérôme, 13397 Cedex 20, Marseille, France

'Aix-Marseille Université Spectropôle - Fédération de Sciences Chimiques de Marseille, FR 1739 Campus de Saint Jérôme, 13397 Cedex 20, Marseille, France

\begin{abstract}
Neste trabalho é descrita a preparação de uma resina modificada, empregada como linker para a preparação de espermidina funcionalizada, em bom rendimento, assim como sua caracterização por infravermelho (IV), ressonância magnética nuclear de ${ }^{13} \mathrm{C}$ no estado sólido com polarização cruzada e rotação no ângulo mágico (RMN-CPMAS de ${ }^{13} \mathrm{C}$ ) e ressonância magnética nuclear de ${ }^{1} \mathrm{H}$ de alta resolução com rotação no ângulo mágico (RMN-MAS de ${ }^{1} \mathrm{H}$ de alta resolução). O linker foi regenerado após clivagem da espermidina e reutilizado sem perda de eficiência.
\end{abstract}

A linker resin for the synthesis of functionalized spermidine in good yield is described, along with its characterization by infrared (IR), ${ }^{13} \mathrm{C}$ solid-state nuclear magnetic resonance with cross polarization and magic angle spinning $\left({ }^{13} \mathrm{C}\right.$ CPMAS NMR) and ${ }^{1} \mathrm{H}$ high resolution magic angle spinning nuclear magnetic resonance ( ${ }^{1} \mathrm{H}$ HRMAS NMR. This linker has been regenerated after cleavage of spermidine and re-used without loss of efficiency.

Keywords: polyamines, ${ }^{13} \mathrm{C}$ CPMAS NMR, HRMAS NMR, solid phase organic synthesis, spermidine

\section{Introduction}

Spermidine is a naturally occurring polyamine, which like other amines as spermine and putrescine, is a growth regulator, besides possessing other unknown biological functions. ${ }^{1}$ In the last years a great deal of attention has been given to naturally occurring polyamines, especially because of their involvement in the regulation of cellular functions such as cell proliferation and differentiation. Antiangiogenic, anticancer, and neurotoxins are some biological activities associated with polyamines and derivatives..$^{2-4}$ The inhibition of enzymes involved in the metabolism of parasitic protozoa has been recognized as a promising strategy for the chemotherapy of tropical diseases. ${ }^{5,6}$ Trypanothione, structurally characterized as $N 1, N 8$-bis(glutathionyl)spermidine, is a polyamine

*e-mail: rsangil@iq.ufrj.br derivative used by trypanosomatids as a defense against reactive oxygen species during their infective cycle. The metabolism of trypanothione is a potential target for drug development against trypanosomiases and leishmanioses. ${ }^{7,8}$ As part of a research program aiming at the synthesis of polyamine derivatives, we became interested in the preparation of selectively protected spermidines. ${ }^{9}$ There are however many synthetic problems associated with polyamine chemistry, such as the amine differentiation and the ability to handle these exceptionally polar compounds. To overcome these obstacles we decided to explore polyamine spermidine synthesis on a solid support with the use of a linker derived from dimethyl-barbituric acid.

Solid phase organic synthesis, SPOS, present established advantages over organic reactions in solution, ${ }^{10-15}$ notably the possibility of using large excess of reagents and a simplification of the isolation procedures with no need of purifications in each step are among the most relevant ones. 


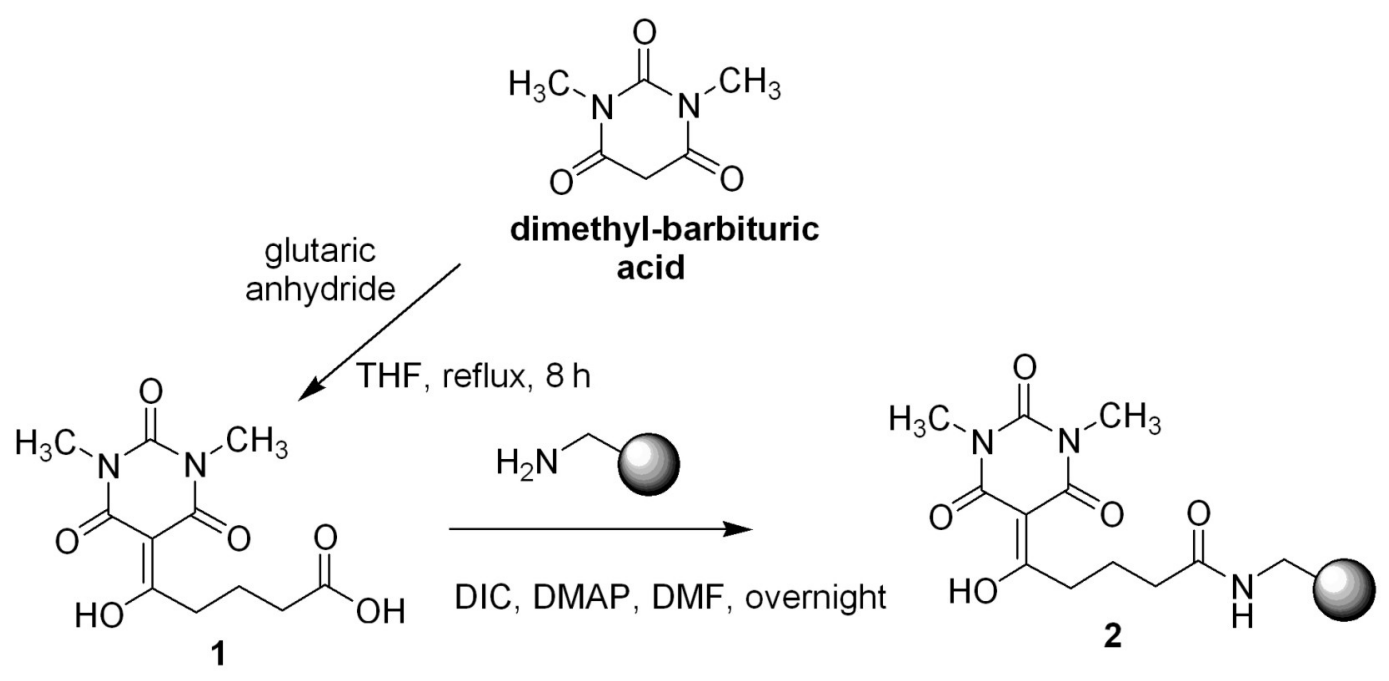

Scheme 1. Synthesis of the linker resin.

Various examples exist of the solid phase synthesis of polyamine conjugates for different purposes. ${ }^{16-19} \mathrm{~A}$ previous paper $^{20}$ described the synthesis of an orthogonally protected spermidine, using the Merrifield resin. ${ }^{21}$ In the present paper a linker resin prepared from dimethyl-barbituric acid and the glutaric anhydride was successfully used in the solidphase synthesis of a selectively protected spermidine.

\section{Results and Discussion}

Dimethyl-barbituric acid was transformed into 1,3-dimethyl-5-glutaryl-barbituric acid $\mathbf{1}$ by reaction with glutaric anhydride in THF at $81 \%$ of yield. ${ }^{22}$ This intermediate was linked to the polymeric resin using standard solid phase conditions by use of the diisopropylcarbodiimide (DIC) and dimethylamine pyridine (DMAP) to produce the linker resin 2 (Scheme 1). ${ }^{23}$ The aminomethyl resin was prepared from Merrifield resin, purchased from Aldrich, as previously described, ${ }^{24}$ and Fmoc loading assay ${ }^{25}$ showed a loading of $0.64 \mathrm{mmol} \mathrm{g}^{-1}$.

Most compounds in Scheme 1 can be characterized by standard liquid-state methods, while for functionalized resins, as $\mathbf{2}$, adapted analytical techniques must be used to follow the reaction in the solid phase. Typically infrared spectroscopy ${ }^{26-29}$ and solid state NMR techniques ${ }^{10,30-32}$ are proper to the task. Figure 1 illustrates the solid-state ${ }^{13} \mathrm{C}$ cross polarization magic angle spinning (CP/MAS) spectra $^{33}$ of compounds $\mathbf{1}$ and $\mathbf{2}$. The signal corresponding to $\mathrm{COOH}$ (at $182.5 \mathrm{ppm}$ ) is not present in the spectra of resin 2. Conversely, the formation of the $\mathrm{N}-\mathrm{C}=\mathrm{O}$ bond caused the broadening of the signal at $\delta 170.2 \mathrm{D}$ TOCSY (total correlation spectroscopy) HR-MAS NMR ${ }^{33}$ also confirmed the amide linkage (Figure 2).

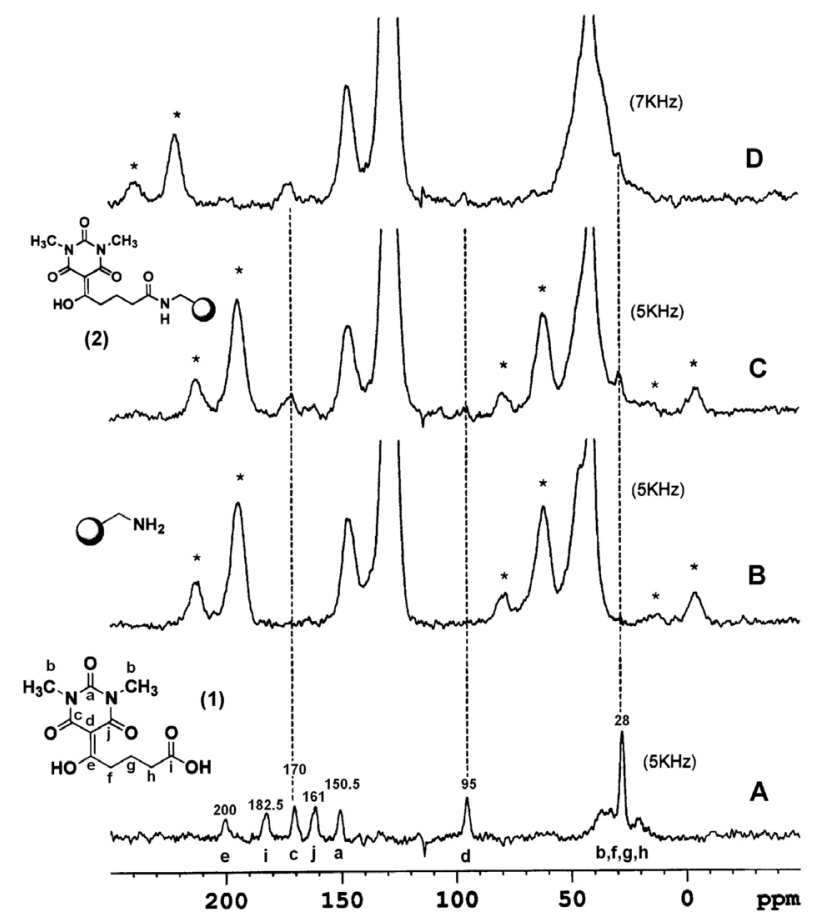

Figure 1. ${ }^{13} \mathrm{C}$ CPMAS solid-state NMR of the products in Scheme 1: (A) 1,3-dimethyl-5-glutaryl-barbituric acid 1; (B) aminomethyl resin; (C) linker resin 2; (D) Merrifield's resin. Spinning sidebands are denoted by asterisks.

The resin $\mathbf{2}$ was then used in the synthesis of spermidine as demonstrated in Scheme 2. In order to initiate the preparation the 2-nitrossulfonamide was anchored on the resin 2 by reaction in THF under reflux. ${ }^{34}$ The resulting resin 3 then reacted with 4-bromobutylphthalimide in acetonitrile in the presence of $\mathrm{Cs}_{2} \mathrm{CO}_{3}$ as base, generating the resin $4 .{ }^{35}$ Protected spermidine $\mathbf{5}^{36}$ was cleaved from resin $\mathbf{4}$ after treatment with hydrate hydrazine at room temperature. 


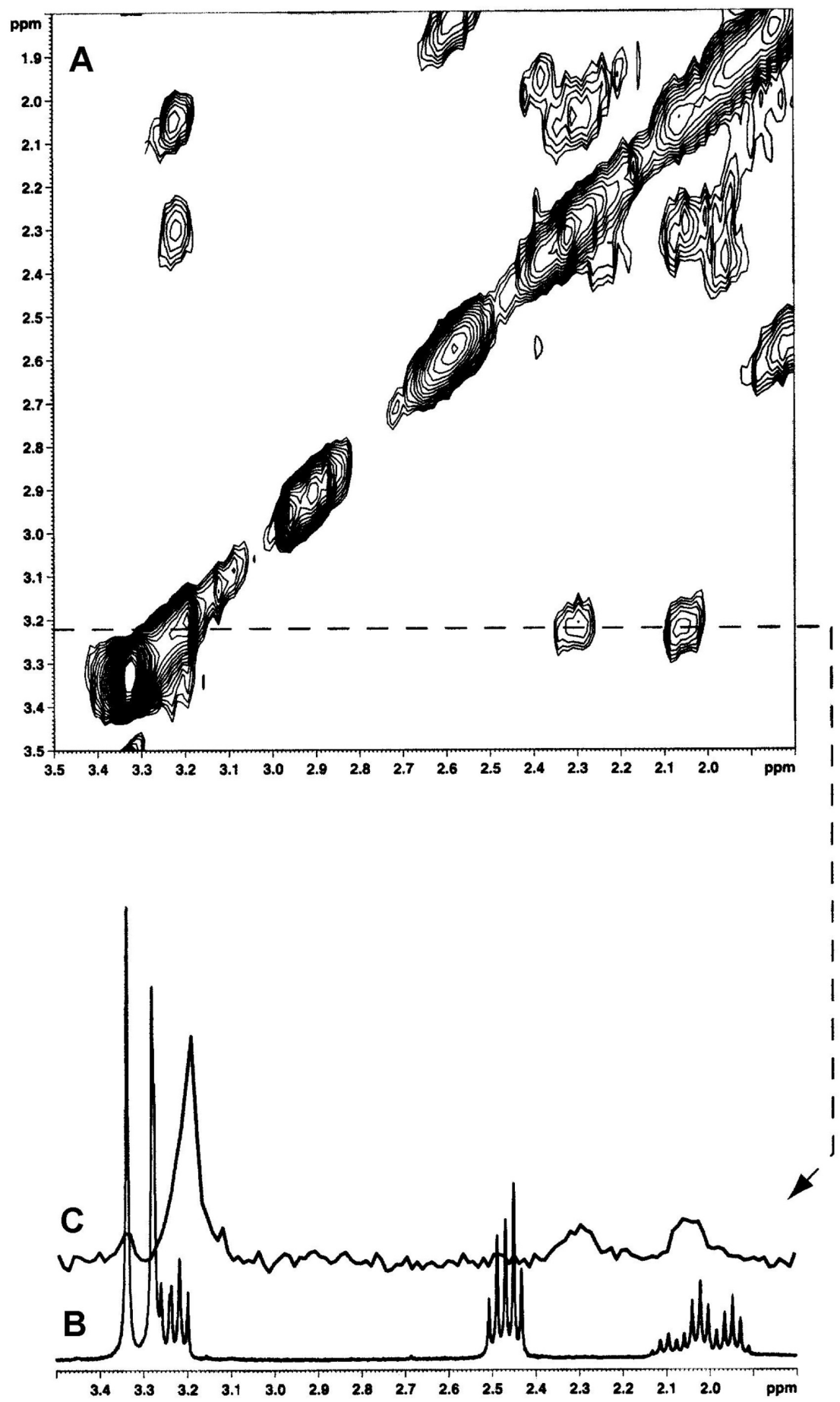

Figure 2. High resolution solid state NMR spectra of the new linker (A) 2D TOCSY; (B) ${ }^{1} \mathrm{H}$ HRMAS; (C) 1D slice of 2D TOCSY spectrum showing the connection between the resin and the linker moiety.

Spermidine 5 was previously prepared by our group in solution system utilizing Fukuyama's sulfonamide. ${ }^{37}$

Resin 2 was then reconstituted (Scheme 3) by treatment of resin $\mathbf{4}$, after cleavage of spermidine, with isopropyl nitrite in presence of $\mathrm{H}_{2} \mathrm{O} / \mathrm{AcOH}$ in THF at room temperature overnight (Scheme 3).

\section{Conclusion}

In summary this communication reports a resin linker for the synthesis of functionalized spermidine. The resin was successfully prepared and characterized using solid state spectroscopic methods, infrared and NMR techniques 


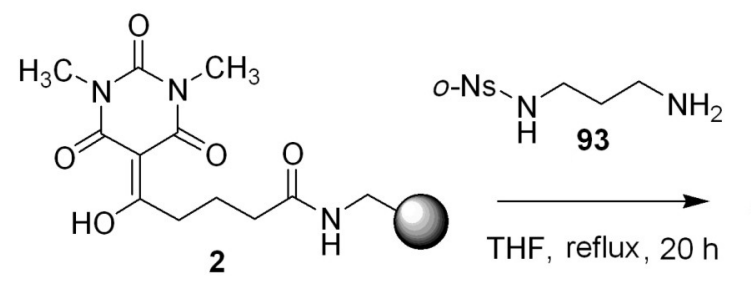<smiles>Cn1c(=O)c(CCCC(=O)NCCO)c(C(=O)NCCCNN=O)c(=O)n1C</smiles>

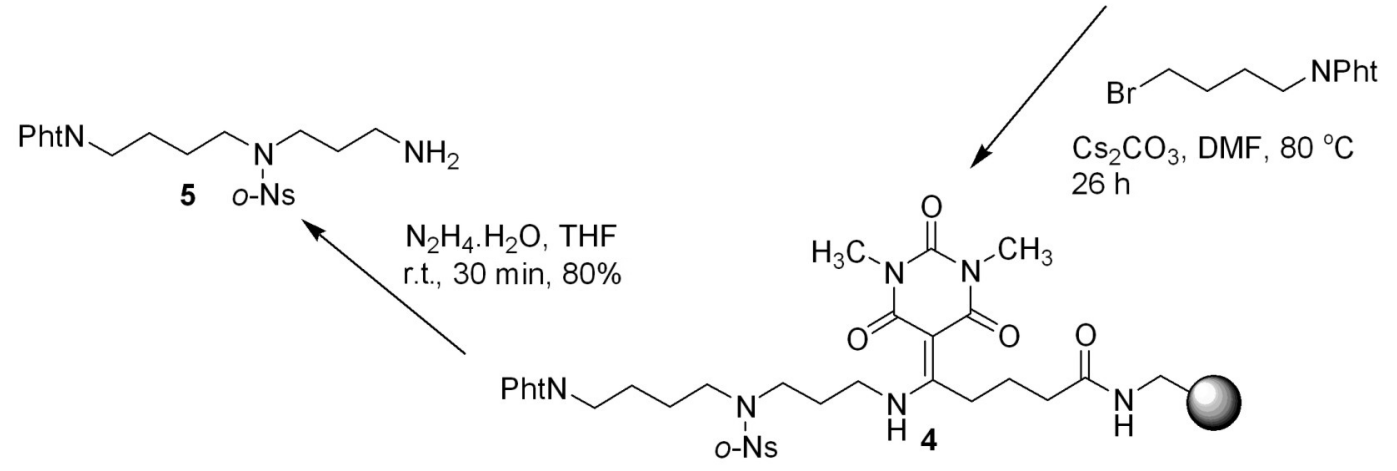

Scheme 2. Synthesis of spermidine $\mathbf{5}$ on a solid support.

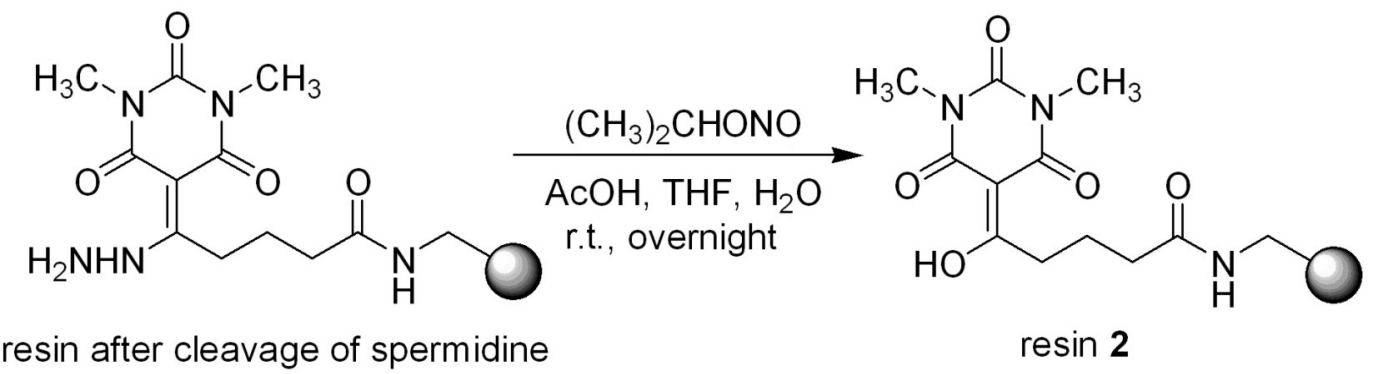

Scheme 3. Reconstitution of resin 2.

in phase solid proving the efficiency of this method. This linker was regenerated after cleavage of spermidine and re-used without loss of efficiency. It can be used similarly to other primary amines.

\section{Acknowledgements}

The authors would like to thank CAPES-COFECUB for support (grant No. 436/03), FAPERJ for schollarship (E. T. da Silva) and CAPES for a visiting professor grant (grant No. 014/2008, S. Caldarelli).

\section{References}

1. Ramya, T. N. C.; Surolia, N.; Surolia, A.; Biochem. Biophys. Res. Commun. 2006, 348, 579.

2. Wallace, H. M.; Niiranen, K.; Amino Acids 2007, 33, 261.
3. Montanez, R.; Sanchez-Jimenez, F.; Aldana-Montes, J. F.; Medina, M. A.; Amino Acids 2007, 33, 283; Cunha, A. S.; Lima, E. L. S.; Pinto, A. C.; Esteves-Souza, A.; Echevarria, A.; Camara, C. A.; Vargas, M. D.; Torres, J. C.; J. Braz. Chem. Soc. 2006, 17, 439.

4. Saunders, F. R.; Wallace, H. M.; Biochem. Soc. Trans. 2007, 35,364 .

5. Hasne, M. P.; Ullman, B.; J. Biol. Chem. 2005, 280, 15188.

6. Nozaki, T.; Ali, V.; Tokoro, M.; Adv. Parasitol. 2005, 60, 1.

7. Hamilton, C. J.; Saravanamuthu, A.; Fairlamb, A. H.; Eggleston, I. M. ; Bioorg. Med. Chem. 2003, 11, 3683.

8. Krauth-Siegel, R. L.; Inhoff, O.; Parasitol. Res. 2003, 90, Suppl. 2, S77.

9. da Silva, E. T.; Lima, E. L. S.; Tetrahedron Lett. 2003, 44, 3621.

10. Pop, I. E.; Dhalluin, C. F.; Déprez, B. P.; Melnyk, P. C.; Lippens, G. M.; Tartar, A. L.; Tetrahedron 1996, 52, 12209. 
11. Seneci, P.; Sizemore, C.; Islam, K.; Kocis, P.; Tetrahedron Lett. 1996, 37, 6319.

12. Rousselot-Pailley, P.; Maux, D.; Wieruszeski, J. M.; Aubagnac, J. L.; Martinez, J.; Lippens, G.; Tetrahedron 2000, 56, 5163.

13. Speicher, A.; Backes, T.; Grosse, S.; Tetrahedron 2005, 61, 11692.

14. Blackburn, C.; Tetrahedron Lett. 2005, 46, 1405.

15. Seneci, P.; Combinatorial Chemistry in Comprehensive Medicinal Chemistry II, vol. 3, $1^{\text {st }}$ ed., Elsevier: London, 2007.

16. Vassis, S.; Karigiannis, G., Balayiannis, G.; Militsopoulou, M.; Mamos, P.; Franis, G. W.; Papaloannou, D.; Tetrahedron Lett. 2001, 42, 1579 .

17. De Luca, S.; Ulhaq, S.; Dixon, M. J.; Essex, J.; Bradley, M.; Tetrahedron Lett. 2003, 44, 3195.

18. Nagata, K.; Fukunaga, T.; Kato, S.; Jyo, A.; React. Funct. Polym. 2008, 68, 1127.

19. Iijima, Y.; Munakata, A.; Shin-ya, K.; Ganesan, A.; Doi, T.; Takahashi, T.; Tetrahedron Lett. 2009, 50, 2970.

20. da Silva, E. T.; Cunha, A. S.; Lima, E. L. S.; Bioorg. Med. Chem. Lett. 2002, 12, 3207.

21. Chhabra, S. R.; Khan, A. N.; Bycroft. B. W.; Tetrahedron Lett. 1998, 39, 3585.

22. Compound 1 (5-(4-carboxybutyryl)-1,3-dimethyl-2,4,6pyrimidinetrione): to a solution of dimethylbarbituric acid (500 mg, $3.21 \mathrm{mmol})$ in dry THF $(15 \mathrm{~mL})$ was added glutaric anhydride (366 mg, $3.21 \mathrm{mmol}$ ) and a few crystals of DMAP. The mixture was stirred at reflux during $8 \mathrm{~h}$ under nitrogen, after which the solvent was removd in the rotovap. The residue was purified by column chromatography on silica gel (230400 mesh, AcOEt/hexane 50\%) to afford the desired product as a pale white solid, $\mathrm{mp} 84-86^{\circ} \mathrm{C} . \mathrm{Rf}=0.58(\mathrm{AcOEt} / \mathrm{hexane}$ $50 \%) ;{ }^{1} \mathrm{H} \mathrm{NMR}\left(\mathrm{CDCl}_{3}, 200 \mathrm{MHz}\right): \delta 17.59(1 \mathrm{H}, \mathrm{s}, \mathrm{OH}), 3.30$ $\left(3 \mathrm{H}, \mathrm{s}, \mathrm{N}-\mathrm{C}_{3}\right), 3.25\left(3 \mathrm{H}, \mathrm{s}, \mathrm{N}-\mathrm{C}_{3}\right), 3.16\left(2 \mathrm{H}, \mathrm{t}, \mathrm{Csp}^{2}-\mathrm{C}_{2}\right.$, $J 7.5 \mathrm{~Hz}) ; 2.42\left(2 \mathrm{H}, \mathrm{t},-\mathrm{C}_{2}-\mathrm{CO}_{2} \mathrm{H}, J 7.5 \mathrm{~Hz}\right) 2.0(2 \mathrm{H}$, qui, $\left.-\mathrm{CH}_{2}-\mathrm{CH}_{2}-\mathrm{CH}_{2}-\right) ;{ }^{13} \mathrm{C} \mathrm{NMR}\left(\mathrm{CDCl}_{3}, 50 \mathrm{MHz}\right): \delta 20.44,28.06$, $28.21,96.02,150.57,161.28,169.60 ;$ IR $v_{\max } / \mathrm{cm}^{-1}: 3432$, 3007, 2962, 1724, 1705, 1669, 1552, 1489, 1264, 1169, 1017, 800, 754, $424(\mathrm{KBr})$. Elemental anal. calc. for $\mathrm{C}_{11} \mathrm{H}_{14} \mathrm{~N}_{2} \mathrm{O}_{6}: \mathrm{C}$, 48.89; H, 5.22; N, 10.37; found: C, 48.86; H, 5.16; N, $10.67 \%$.

23. Resin 2: aminomethyl resin ( $1 \mathrm{~g}$; load $\left.0.64 \mathrm{mmol} \mathrm{g} \mathrm{g}^{-1}\right)$ was swelled with DMF $(15 \mathrm{~mL})$, then were added $457 \mathrm{mg}$ ( $1.8 \mathrm{mmol}$; 2.8 equiv.) of compound $\mathbf{1}$, a few crystals of DMAP and DIC (1.8 mol; 2.8 equiv.) and the mixture gently agitated overnight when ninhydrin test indicated the total consumption of free amino group. The resin was filtered and washed with $\mathrm{DMF}(3 \times 15 \mathrm{~mL})$, THF $(3 \times 15 \mathrm{~mL}), \mathrm{EtOH}(3 \times 15 \mathrm{~mL}), \mathrm{CH}_{2} \mathrm{Cl}_{2}(3 \times 15 \mathrm{~mL})$. Then the resin was dried under vacuum. IR $v_{\max } / \mathrm{cm}^{-1}: 3412$, 3326, 3058, 3023, 2916, 2848, 1723, 1668, 1557, 1490, 1450, 1353, 1026, 1269, 754, 535 (KBr). ${ }^{1} \mathrm{H}$ HRMAS NMR TOCSY correlation peaks of the $\left(\mathrm{XC}=\mathrm{OCH}_{2} \mathrm{CH}_{2} \mathrm{CH}_{2} \mathrm{COH}=\right)$ spin system: $3.2\left(\mathrm{CH}_{2} \mathrm{CO} \underline{\mathrm{H}}=\right) ; 2.3\left(-\mathrm{C}_{2}-\mathrm{CO}_{2} \mathrm{H}\right) ; 2.05 \mathrm{ppm}\left(-\mathrm{CH}_{2}-\mathrm{C}_{2}-\mathrm{CH}_{2}-\right)$.
24. Weinshenker, N. M.; Shen, C. M.; Tetrahedron Lett. 1972, 32, 3281.

25. Atherton, E.; Benoiton, N. L.; Brown, E.; Sheppard, R. C.; Williams, B. J.; Chem. Commun. 1981, 7, 336.

26. Huber, W.; Bubendorf, A.; Grieder, A.; Obrecht, D.; Anal. Chim. Acta 1999, 393, 213.

27. Drewry, D. H.; Ghiron, C.; Tetrahedron Lett. 2000, 41, 6989.

28. Volonterio, A.; Chiva, G.; Fustero, S.; Piera, J.; Rosello, M. S.; Sani, M.; Zanda, M.; Tetrahedron Lett. 2003, 44, 7019.

29. Sreejalekshmi, K. G.; Devi, S. K. C.; Rajasekharan, K. N.; Tetrahedron Lett. 2006, 47, 6179.

30. Arai, T.; Fujiwara, A.; Watanabe, M.; Yokoyama, T. F.; Deguchi, K.; Yanagisawa, A.; Tetrahedron Lett. 2006, 47, 1673.

31. Anderson, R. C.; Stokes, J. P.; Shapiro, M. J.; Tetrahedron Lett. 1995, 36, 5311.

32. Lin, M. F.; Shapiro, M. J.; J. Org. Chem. 1996, 61, 7617.

33. Solid state ${ }^{13} \mathrm{C}$ CPMAS spectra were acquired on a Bruker DRX300 spectrometer (7.05 T), operating at 75.4 MHz, using a $4 \mathrm{~mm}$ Bruker CPMAS probehead and $4 \mathrm{~mm} \mathrm{ZrO}_{2}$ rotor with Kel-F stoppers, spinning at 5 and $7 \mathrm{kHz}$. Acquis. parameters: $\mathrm{P}_{1} 5 \mu \mathrm{s}$, contact time (optimized) of $3 \mathrm{~ms}$, recycle time $2 \mathrm{~s}$, number of scans 1000. Hexamethyl benzene was used as external reference $\left(\mathrm{CH}_{3}\right.$ at $\left.17.3 \mathrm{ppm}\right) .{ }^{1} \mathrm{H}$ HRMAS NMR spectra were obtained on a Bruker DSX400 instrument, equipped with a $4 \mathrm{~mm}$ dual ${ }^{1} \mathrm{H} /{ }^{13} \mathrm{C}$ high resolution MAS probehead, using 1 to $2.5 \mathrm{mg}$ of sample swollen in 12 to $50 \mu \mathrm{L} \mathrm{CD}_{2} \mathrm{Cl}_{2}$, pulse delay $10 \mathrm{~s}, 256$ scans and spinning rate of $4000 \mathrm{~Hz}$. 2D-TOCSY spectra were recorded with a mixing time of $85 \mathrm{~ms}, 16$ transients and $3500 \mathrm{~Hz}$ of rotation frequency. Chemical shifts $(\delta)$ for ${ }^{1} \mathrm{H}$ MAS NMR are reported in ppm relative to residual signal of $\mathrm{CD}_{2} \mathrm{Cl}_{2}$.

34. Resin 3: Resin 2 (500 mg; load: $0.55 \mathrm{mmol} \mathrm{g}^{-1}$ ) was swelled with dry THF $(10 \mathrm{~mL})$ and submitted to reaction with 2-nitrosulfonamidopropylamine (616 mg; 10 equiv.) under reflux for $20 \mathrm{~h}$. After this time the resin was filtered and washed with $\mathrm{THF}(3 \times 10 \mathrm{~mL})$, isopropanol $(3 \times 10 \mathrm{~mL}), \mathrm{MeOH}(3 \times 10 \mathrm{~mL})$, $\mathrm{CH}_{2} \mathrm{Cl}_{2}(3 \times 10 \mathrm{~mL})$. The resin was dried under vacuum. IR $v_{\max } / \mathrm{cm}^{-1}: 3415,3024,2921,1706,1672,1643,1590,1492$, $1451,1348,1166,758,700,539(\mathrm{KBr})$.

35. Resin 4: To a suspension of resin 3 (500 mg; load $0.49 \mathrm{mmol} \mathrm{g}^{-1}$ ) swelled with dry DMF was added $798 \mathrm{mg}$ (2.45 mmol; 10 equiv.) of cesium carbonate and $346 \mathrm{mg}$ (1.22 mmol; 5 equiv.) of $\mathrm{N}$-(4-bromobutyl)phthalimide. Ther reaction was gently stirred at $80{ }^{\circ} \mathrm{C}$ for $26 \mathrm{~h}$. Then, the resin was filtered and washed with $\mathrm{DMF}(3 \times 10 \mathrm{~mL})$, isopropanol $(3 \times 10 \mathrm{~mL})$, $\mathrm{MeOH}(3 \times 10 \mathrm{~mL}), \mathrm{H}_{2} \mathrm{O}(3 \times 10 \mathrm{~mL}), \mathrm{MeOH}(3 \times 10 \mathrm{~mL})$, $\mathrm{CH}_{2} \mathrm{Cl}_{2}(3 \times 10 \mathrm{~mL})$. The resin was dried under vacuum. IR $v_{\text {max }}$ ' $\mathrm{cm}^{-1}$ : 3409, 3024, 292, 1704, 1640, 1584, 1492, 1451, 1372, $1272,1166,758,700,541(\mathrm{KBr})$.

36. Compound 5: Resin 4 (500 mg; load $0.45 \mathrm{mmol} \mathrm{g}^{-1}$ ) was swelled with dry THF $(10 \mathrm{~mL})$ and submitted to reaction with 5 equiv. of hydrazine hidrate at room temperature for $30 \mathrm{~min}$. After the 
resin was filtered and washed with $\mathrm{THF}(3 \times 5 \mathrm{~mL})$ and $\mathrm{CH}_{2} \mathrm{Cl}_{2}$ $(3 \times 5 \mathrm{~mL})$. The solvent was removed at reduced pressure and the residue obtained was poured into water and extracted with ethyl acetate $(3 \times 10 \mathrm{~mL})$. The organic layer was dried over anhydrous sodium sulfate and concentrated, furnishing an oil that after purification by flash chromatography $\left(\mathrm{SiO}_{2}\right.$, 230-400 mesh, $\mathrm{MeOH} / \mathrm{Et}_{3} \mathrm{~N} 50 \%$ ) yield $80 \%$ of spermidine 5 as a colorless oil. $\mathrm{Rf}=0.65\left(\mathrm{MeOH} / \mathrm{Et}_{3} \mathrm{~N} 50 \%\right) ; \mathrm{IR} v_{\max } / \mathrm{cm}^{-1}$ : 3450, 2930, 2854, 1711, 1593, 1543, 1477, 1161 (film); ${ }^{1} \mathrm{H}$ NMR (200 MHz, $\left.\mathrm{CDCl}_{3}\right): \delta$ 1.47-1.85 (m, 6H, $\left.\mathrm{CH}_{2}\right), 2.41$ (m, 4H, - $\left.\underline{\mathrm{H}}_{2}-\mathrm{NNs}-\underline{\mathrm{C}}_{2}-\right) ; 2.79$ (sl, 2H, $\left.\underline{\mathrm{H}}_{2}\right) ; 3.58$ (t, 2H, $J$ $\left.6.91 \mathrm{~Hz},-\underline{\mathrm{C}}_{2} \mathrm{NPht}\right) ; 7.55-8.10$ (m, 8H, Ar$\left.\underline{\mathrm{H}}\right) ;{ }^{13} \mathrm{C}$ NMR (50 $\left.\mathrm{MHz}, \mathrm{CDCl}_{3}\right): \delta 23.48,26.49,37.85,39.69,58.52,52.04$, 52.99, 123.38, 124.30, 131.10, 131.95, 132.24, 133.10, 133.90, 134.08, 148.20, 168.50.

37. da Silva, E. T. ; Fona, F. S.;Lima, E. L. S.; J. Braz. Chem. Soc. 2004, 15, 433.

Submitted: May 17, 2010 Published online: August 12, 2010 